\title{
Analysis of Academic Research Award Policy in Bohai University
}

\author{
Le Wang a and Yanlong Jin ${ }^{b, *}$ \\ Bohai University, Jinzhou, Liaoning, China \\ alewang1982@163.com, b49718990@qq.com
}

\section{Keywords: Academic Research Projects; Academic Papers; Research Awards; Incentive Effects}

\begin{abstract}
Academic research is one of the main tasks of university teachers. Many Chinese universities have issued incentive policies for academic research. This paper analyzes the categories and monetary awards of academic research in Bohai University, analyzes the incentive effect of academic research awards and both advantages and disadvantages. The result shows that, in recent years, the academic research ability of Bohai University has improved significantly, but there are still some problems need to be solved. Therefore, the academic research award policy of Bohai University should be constantly optimized so as to play a better incentive effect.
\end{abstract}

\section{Introduction}

University teachers are different from primary and secondary school teachers. Besides teaching knowledge, they also need to conducted academic research. ${ }^{[1]}$ The quality of academic research achievements can affect the reputation of university, and many universities encourage teachers to conducted academic research. ${ }^{[2-5]}$

Bohai University is a comprehensive university, located in Liaoning, China, with over 1200 faculty members, including over 200 professors and nearly 500 associate professors, and has a total enrollment of over 21,900 degree candidates, including undergraduate, graduate, and vocational students.

Many years ago, Bohai University began to award teachers' academic research. The academic reward policy of Bohai University is adjusted every few years, according to the number of achievements. The current award document was issued in November $11,2016 .{ }^{[6]}$ This paper will analyze the categories and monetary award of academic research awards of Bohai University, evaluates the incentive effect of academic research awards, analyzes current problems, and finally puts forward some suggestions.

\section{The categories and monetary award of academic research awards of Bohai University}

Bohai University's academic research awards are only awarded to the first person in charge of the academic research achievements, and the first institution of achievements must be Bohai University. The achievements must be uncontroversial and non-plagiarized. The award categories include important academic papers, papers cited or reprinted, patents, academic research projects, prizes from government, and proposals instructed by leaders or adopted by government department.

Important academic papers refer to papers published in journals such as Nature, Science and other SCI, EI, SSCI, CSSCI(Chinese Social Sciences Citation Index), PKU(Chinese Core Journals from Peking University Library) journals, etc. Papers cited or reprinted refer to China top 100 most cited Chinese papers published in international journals, ESI Highly Cited Papers, ESI Hot Papers, etc. Patents award only reward invention patents; excluding utility models, industrial design rights and software copyright. Academic research projects include longitudinal projects and horizontal projects. Longitudinal projects refer to projects approved by governments at all levels, and horizontal projects refer to projects approved by enterprises. Awards from government include State Science and Technology Awards, provincial academic research awards, and municipal academic research award. Proposals instructed by leaders or adopted by government departments include instructed by State leaders, instructed by provincial leaders, adopted by Departments of State Council of China, adopted by departments of government of Liaoning Province. 
The monetary award of important academic papers is shown in Table 1. SCI classification and influencing factors are used in the JCR journal sub regional data of Centre for Documentation and Information, Chinese Academy of Sciences. The extra reward is based on the cooperation with the lowest impact factor of the selected journals in this subject; the reward quota will rise by 1,000 yuan for each higher impact factor. When an artistic work reaches the full page, it can be regarded as one academic paper to be rewarded with the corresponding grade. When it reaches $3 / 4$ pages, $1 / 2$ pages or $1 / 4$ pages, it is rewarded by $3 / 4,1 / 2$ and $1 / 4$ of one corresponding grade academic paper.

Table 1 The monetary award of important academic papers in Bohai University

\begin{tabular}{|c|c|c|c|}
\hline \multicolumn{3}{|c|}{ Types of Academic Journals } & Monetary Award (RMB /per paper) \\
\hline \multicolumn{3}{|c|}{ Nature, Science } & 500,000 \\
\hline \multicolumn{3}{|c|}{ Science China, Social Sciences in China } & 20,000 \\
\hline \multirow{4}{*}{ SCI } & \multicolumn{2}{|c|}{ The top level } & $20,000+$ Extra reward \\
\hline & \multicolumn{2}{|c|}{ The secondary level } & $12,000+$ Extra reward \\
\hline & \multicolumn{2}{|c|}{ The third level } & 6,000 \\
\hline & \multicolumn{2}{|c|}{ The fourth level } & 4,000 \\
\hline \multicolumn{3}{|c|}{ SSCI } & 12,000 \\
\hline \multicolumn{3}{|c|}{ ISR, AHCI } & 5,000 \\
\hline \multicolumn{3}{|c|}{ CSSCI(Chinese Social Sciences Citation Index) } & 6,000 \\
\hline \multicolumn{3}{|c|}{ EI Journals } & 3,000 \\
\hline \multicolumn{3}{|c|}{ EI Conference Papers, CPCI-S, CPCI-SSH } & 2,000 \\
\hline \multicolumn{3}{|c|}{ PKU Journals, SCD (Science Citation Database) } & 1,000 \\
\hline \multirow{2}{*}{\multicolumn{2}{|c|}{$\begin{array}{l}\text { "People's Daily" Theory } \\
\text { "Guang Ming Daily" Theory }\end{array}$}} & $>2000$ characters & 6,000 \\
\hline & & 1000-2000 characters & 2,000 \\
\hline \multicolumn{3}{|c|}{ China Education Daily $>1000$ characters } & 2,000 \\
\hline
\end{tabular}

Papers cited or reprinted refer to China top 100 most cited Chinese papers published in international journals, ESI Highly Cited Papers, ESI Hot Papers, etc. The monetary award of papers cited or reprinted is shown in Table 2.

Table 2 The monetary award of papers cited or reprinted in Bohai University

\begin{tabular}{|l|c|}
\hline Types of Cited or Reprinted Papers & Monetary Award (RMB /per paper) \\
\hline $\begin{array}{l}\text { China top 100 most cited Chinese papers published in } \\
\text { international journals }\end{array}$ & 100,000 \\
\hline ESI Highly Cited Papers & 50,000 \\
\hline ESI Hot Papers & 30,000 \\
\hline "XinHua Digest" full text reprint & 12,000 \\
\hline "XinHua Digest" partial reprint & 6,000 \\
\hline "XinHua Digest" main ideas reprint & 1,000 \\
\hline $\begin{array}{l}\text { China Social Sciences Digest (CSSD); China } \\
\text { University Academic Abstracts (CUAA); Newspaper } \\
\text { and Periodical Index by Chinese People's University }\end{array}$ & 1,000 \\
\hline
\end{tabular}

Patents award only reward invention patents; excluding utility models, industrial design rights and software copyright. Before 2016, the award limit for invention patents was 30,000 Yuan, but now it is 6,000 Yuan because some teachers have applied for too many patents.

Academic research projects include longitudinal projects and horizontal projects. Longitudinal projects refer to projects approved by governments at all levels, and horizontal projects refer to projects approved by enterprises. The monetary award of academic research projects is shown in Table 3 . 
Table 3 The monetary award of academic research projects in Bohai University

\begin{tabular}{|l|l|c|}
\hline \multicolumn{1}{|l|}{ Types of Academic Research Projects } & Monetary Award Ratio \\
\hline \multirow{4}{*}{$\begin{array}{l}\text { Longitudinal } \\
\text { projects }\end{array}$} & National research projects & Project funds*50\% \\
\cline { 2 - 3 } & National research projects (No funds) & 20,000 as the research funds \\
\cline { 2 - 3 } & Sub-project of national major project & Project funds*10\% \\
\cline { 2 - 3 } & Provincial and ministerial level projects & Project funds* $10 \%$ \\
\cline { 2 - 3 } & Provincial department of education project & Project funds*5\% \\
\cline { 2 - 3 } & Provincial social science association project & Project funds*5\% \\
\cline { 2 - 3 } & Municipal research project & Project funds*5\% \\
\hline Horizontal projects (from enterprises) & Project funds*5\% \\
\hline
\end{tabular}

Awards from government include State Science and Technology Awards, provincial academic research awards, and municipal academic research award. The monetary award of prizes from government is shown in Table 4.

Table 4 The monetary award of awards from government in Bohai University

\begin{tabular}{|c|c|c|c|c|c|}
\hline \multicolumn{2}{|c|}{ Types of Awards from Government } & $\begin{array}{l}\text { Grand } \\
\text { award }\end{array}$ & First award & $\begin{array}{l}\text { Second } \\
\text { award }\end{array}$ & $\begin{array}{l}\text { Third } \\
\text { award }\end{array}$ \\
\hline \multirow{4}{*}{$\begin{array}{l}\text { State } \\
\text { awards }\end{array}$} & The State Natural Science Award & $5,000,000$ & $3,000,000$ & $2,000,000$ & - \\
\hline & $\begin{array}{l}\text { The State Technological Invention } \\
\text { Award }\end{array}$ & $5,000,000$ & $3,000,000$ & $2,000,000$ & - \\
\hline & $\begin{array}{l}\text { The State Scientific and } \\
\text { Technological Progress Award }\end{array}$ & $5,000,000$ & $3,000,000$ & $2,000,000$ & - \\
\hline & $\begin{array}{l}\text { Outstanding Achievement Award of } \\
\text { National Social Science Fund Project }\end{array}$ & - & 120,000 & 100,000 & 80,000 \\
\hline \multirow{6}{*}{$\begin{array}{l}\text { Provincial } \\
\text { and } \\
\text { ministerial } \\
\text { Awards }\end{array}$} & $\begin{array}{l}\text { Outstanding Achievement Award for } \\
\text { Scientific Research in Universities } \\
\text { (Science and Technology) }\end{array}$ & - & 150,000 & 90,000 & 60,000 \\
\hline & $\begin{array}{l}\text { Outstanding Achievement Award for } \\
\text { Scientific Research in Universities } \\
\text { (Humanities and Social Sciences) }\end{array}$ & - & 100,000 & 80,000 & 60,000 \\
\hline & $\begin{array}{l}\text { Natural Science Award of Liaoning } \\
\text { Province }\end{array}$ & - & 150,000 & 90,000 & 60,000 \\
\hline & $\begin{array}{l}\text { Technological Invention Award of } \\
\text { Liaoning Province }\end{array}$ & - & 150,000 & 90,000 & 60,000 \\
\hline & $\begin{array}{l}\text { Scientific and Technological Progress } \\
\text { Award of Liaoning Province }\end{array}$ & - & 150,000 & 90,000 & 60,000 \\
\hline & $\begin{array}{l}\text { Philosophy and Social Sciences } \\
\text { Achievement Award of Liaoning } \\
\text { Province }\end{array}$ & - & 30,000 & 15,000 & 10,000 \\
\hline \multirow{4}{*}{$\begin{array}{l}\text { Municipal } \\
\text { Award }\end{array}$} & $\begin{array}{l}\text { Science and Technology Progress } \\
\text { Award of Jinzhou City }\end{array}$ & - & 20,000 & 10,000 & 5,000 \\
\hline & $\begin{array}{l}\text { Science and Technology Award of } \\
\text { Jinzhou City (Tackle Key Problems) }\end{array}$ & - & 4,000 & 2,000 & 1,000 \\
\hline & $\begin{array}{l}\text { Monographs Award of Philosophy } \\
\text { and Social Sciences of Jinzhou City }\end{array}$ & - & 2,000 & 1,200 & 600 \\
\hline & $\begin{array}{l}\text { Papers Award of Philosophy and } \\
\text { Social Sciences of Jinzhou City }\end{array}$ & - & 1,000 & 600 & 300 \\
\hline
\end{tabular}

Proposals instructed by leaders or adopted by government departments include instructed by State leaders, instructed by provincial leaders, adopted by Departments of State Council of China, adopted by departments of government of Liaoning Province. The monetary award of proposals instructed by leaders or adopted by government departments is shown in Table 5. 
Table 5 The monetary award of proposals in Bohai University

\begin{tabular}{|l|c|}
\hline Types of Proposals & Monetary Award \\
\hline Instructed by State leaders & 30,000 \\
\hline Adopted by Departments of State Council of China (meanwhile) & 30,000 \\
\hline Instructed by provincial leaders & 4,000 \\
\hline $\begin{array}{l}\text { Adopted by departments of government of Liaoning Province } \\
\text { (meanwhile) }\end{array}$ & 4,000 \\
\hline
\end{tabular}

\section{The incentive effect of academic research awards}

According to the official website, Bohai University has made great achievements in scientific research in recent years. ${ }^{[7]}$ Since 2011, the teachers of BU have been approved more than 2,500 research projects at various levels, including the national "Project 863", National Fund Project for Natural Science, National Fund Project for Social Science, and other key projects at the levels of Ministry of Science and Technology, the Ministry of Education or Liaoning Province. All kinds of achievements were awarded more than 1300 times. The teachers of Bohai University has published over 11,00 papers, and over 2,500 papers were indexed by SCI, EI and CPCI. And BU has been authorized more than 300 invention patents.

According to the latest ESI data released by Thomson Reuters in May 2017, Bohai University's engineering and chemistry disciplines are among the top $1 \%$ of the world's ESI disciplines. In November 2017, Professor Gang Han published the paper "A Jurassic gliding euharamiyidan mammal with an ear of five auditory bones" on Nature, which is the first Nature paper of Bohai University. In January 2018, Professor Jianrong Li won the second prize of the National Science and Technology Progress Award, and achieved a historical breakthrough in the university's national awards. These data show that the scientific research awards of Bohai University have achieved positive results.

\section{The advantages of academic research awards of Bohai University}

First of all, Bohai University has a high academic research award. For example, the monetary award of Nature and Science is 500,000. And the monetary award of grand award of The State Natural Science Award is 5,000,000. High award motivates teachers' confidence and plays a positive role in promoting scientific research achievements.

Secondly, there are many kinds of awards. The award categories include important academic papers, papers cited or reprinted, patents, academic research projects, prizes from government, and proposals instructed by leaders or adopted by government department. Teachers can be awarded from various sources.

Thirdly, the award not only focuses on the quantity of achievements, but also the quality of the achievements. The SCI journals are divided into four levels. China top 100 most cited Chinese papers published in international journals, ESI Highly Cited Papers, and ESI Hot Papers will get extra awards.

\section{The disadvantages of academic research awards of Bohai University}

First, Bohai University pays more attention to scientific research than teaching. The achievements in teaching research and teaching practice have not been rewarded enough. Secondly, Bohai University pays more attention to natural science than humanities and social sciences. It can be seen from the amount of research awards. Finally, some teachers have not been awarded or get very little awards for many years, so the award policy has not played an incentive role for these teachers.

\section{Summary}

This paper analyzes the categories and monetary award of academic research awards of Bohai University, analyzes the incentive effect of academic research awards and both advantages and 
disadvantages. The result shows that, in recent years, the academic research ability of Bohai University has improved significantly, but there are still some problems need to be solved. Therefore, the academic research award policy of Bohai University should be constantly optimized so as to play a better incentive effect.

\section{Acknowledgements}

This research was supported by the University Basic Scientific Research Foundation of Department of Education of Liaoning Province "Research on the mechanism and countermeasures of enhancing teachers' sense of responsibility and improving teachers' professional ability (WY2016007)", and the Research Project on Teaching Reform of Bohai University (BDJG2016QB01).

\section{References}

[1] W. Clark: Academic Charisma and the Origins of the Research University, University of Chicago Press (2006).

[2] M. Khosrowjerdi , Z.S. Kashani: Webolog, Vol.10 (2013) No.2, p.1-9.

[3] K. Soh: Journal of Higher Education Policy \& Management, Vol.39 (2017), p.1-12.

[4] F. Anowar, M.A. Helal, S. Afroj, S. Sultana: F Sarke: Lecture Notes in Electrical Engineering, Vol.312 (2015) p.559-566.

[5] J Harrison: Journal of Higher Education Policy \& Management, Vol.36 (2014) No.5, p.471-482.

[6] Bohai University: Bohai University Award for Scientific Research, November 11, 2016.

[7] Bohai University: About BU. http://www.bhu.edu.cn/en/xxgk_index.asp 